\title{
High BMI: A New Determinant of Impaired Rubella Immunity During Pregnancy?
}

\author{
Catherine J. Andersen \\ Fairfield University, candersen@fairfield.edu
}

Follow this and additional works at: https://digitalcommons.fairfield.edu/biology-facultypubs

(c) The Obesity Society, published by Wiley

The author post-print has been archived here with permission from the copyright holder.

This is the peer reviewed version of the following article: Andersen, C. J. (2018). High BMI: A New Determinant of Impaired Rubella Immunity During Pregnancy?. Obesity (Silver Spring, Md.), 26(9), 1390-1390, which has been published in final form at https://doi.org/10.1002/oby.22286. This article may be used for non-commercial purposes in accordance with Wiley Terms and Conditions for Use of Self-Archived Versions.

\section{Peer Reviewed}

\section{Repository Citation}

Andersen, Catherine J., "High BMI: A New Determinant of Impaired Rubella Immunity During Pregnancy?" (2018). Biology Faculty Publications. 65.

https://digitalcommons.fairfield.edu/biology-facultypubs/65

\section{Published Citation}

Andersen, C. J. (2018). High BMI: A New Determinant of Impaired Rubella Immunity During Pregnancy?. Obesity (Silver Spring, Md.), 26(9), 1390-1390. doi: 10.1002/oby.22286.

This item has been accepted for inclusion in DigitalCommons@Fairfield by an authorized administrator of DigitalCommons@Fairfield. It is brought to you by DigitalCommons@Fairfield with permission from the rightsholder(s) and is protected by copyright and/or related rights. You are free to use this item in any way that is permitted by the copyright and related rights legislation that applies to your use. For other uses, you need to obtain permission from the rights-holder(s) directly, unless additional rights are indicated by a Creative Commons license in the record and/or on the work itself. For more information, please contact digitalcommons@fairfield.edu. 


\section{Commentary}

3 High BMI: A New Determinant of Impaired Rubella Immunity during Pregnancy?

5 Catherine J. Andersen

6

7 Department of Biology, Fairfield University, 1073 North Benson Road, Fairfield, CT 06824.

9 Correspondence: Catherine J. Andersen, candersen@ fairfield.edu

11 Universal immunization programs have been implemented in many countries worldwide, and have

12 significantly lowered the incidence and spread of infectious disease. The effective measles, 13 mumps, and rubella (MMR) vaccine is widely-administered globally (1); however, recent studies

14 have demonstrated a decline in protective anti-rubella antibodies in countries with universal

15 vaccination programs - including among women of reproductive age, thus increasing risk of 16 rubella infection and severe birth defects due to congenital rubella syndrome $(2,3)$.

18 While various factors have been associated with declining rubella immunity following childhood 19 immunization, Hui et al. (4) present compelling evidence to suggest that elevated body mass index

20 (BMI) may impair serological immunity against rubella in pregnant women. In this large-scale

21 retrospective cohort study, pregnant women with BMI > $25.0 \mathrm{~kg} / \mathrm{m}^{2}$ were more likely to present

22 with serological rubella non-immunity (rubella $\mathrm{IgG}$ antibody titre $<10 \mathrm{IU} / \mathrm{ml}$ ), as compared to

23 women with BMI $<25.0 \mathrm{~kg} / \mathrm{m}^{2}$. Interestingly, the risk of rubella non-immunity in women with 
24 high BMI was greater in women born in Hong Kong, where rubella immunization is mandatory

25 during childhood. The positive association between rubella non-immunity and high BMI persisted

26 after controlling for potential confounding factors, such as maternal age, parity, short stature, as

27 well as year and location of birth, which could impact participation in immunization programs.

29 Obesity can impair the regulation of immune responses by promoting lipid deposition in lymphoid 30 tissues, alterations in leukocyte profiles and activity, and chronic inflammation. While studies have

31 previously demonstrated that obesity negatively impacts the efficacy of vaccines against influenza,

32 hepatitis B and tetanus (5), the current work of Hui et al. (4) is novel in that is one of few studies

33 to find an association between high BMI and immunity against rubella, and the first study to

34 identify this trend in pregnant women - a population most at risk for conferring severe effects of 35 rubella infection to offspring.

37 While obesity initiatives often focus on reducing the risk of chronic diseases stemming from

38 metabolic dysfunction (e.g. cardiovascular disease, type 2 diabetes mellitus)(5), these findings

39 emphasize the importance of targeting overweight and obesity as a means to reduce the risk of 40 infectious disease. Given that this current study was conducted in geographical areas where 41 mandatory rubella immunization programs have implemented, these findings call into question the

42 long-term success of these initiatives in preventing rubella outbreaks where the prevalence of 43 overweight and obesity is high. Further investigation may be warranted to determine the need for

44 serological screening and booster immunizations on the basis of BMI, particularly within the 45 context of antenatal care, as a means to promote population health.

\section{References}


48 1. Orenstein WA, Himan A, Nkowane B, Olive JM, and Reingold A. Measles and Rubella

49 Global Strategic Plan 2012-2020 midterm review. Vaccine 2018;36: A1-A34.

50

51 2. Seagle EE, Bednarczyk RA, Hill T, Fiebelkorn AP, Hickman CJ, Icenogle JP, Belongia EA, 52 McLean HQ. Measles, mumps, and rubella antibody patterns of persistence and rate of

53 decline following the second dose of the MMR vaccine. Vaccine 2018;36(6):818-826.

54

55 3. Lin C-C, Yang C-Y, Shih Y-L, Huang Y-Y, Yang T-H, Liang J-Y, Chang C-F, Hsieh H-S,

56 Huang Y-L. Persistence and Titer Changes of Rubella Virus Antibodies in Primiparous

57 Women Who Had Been Vaccinated with Strain RA 27/3 in Junior High School. Clinical and

$58 \quad$ Vaccine Immunology 2012;19(1):1-4.

59

60 4. Hui SYA, Sahota DS, and Lao TT. Impact of Maternal Body Mass Index on Rubella Non-

$61 \quad$ Immunity at Antenatal Screening. Obesity 2018; : .

62

63 5. Andersen CJ, Murphy KE, Fernandez ML. Impact of Obesity and Metabolic Syndrome on

64 Immunity. Advances in Nutrition 2016;7:66-75.

65

66

67 Disclosure: The author declares no conflict of interest. 